\title{
Analysis of Indonesian Languae Mistake in Narrative Essay of Students Class VII Junior High School Gudang Arang in Merauke
}

\author{
$1^{\text {st }}$ Santy Monika* \\ Department of Indonesian Language \\ and Literature \\ Universitas Musamus \\ Merauke, Indonesia \\ monika_fkip@unmus.ac.id
}

\author{
$2^{\text {st }}$ Nova Lina Sari Habeahan \\ Department of Indonesian Language \\ and Literature \\ Universitas Musamus \\ Merauke, Indonesia \\ habeahan_fkip@unmus.ac.id
}

\author{
$3^{\text {st }}$ Lay Riwu \\ Department of Indonesian Language \\ and Literature \\ Universitas Musamus \\ Merauke, Indonesia \\ riwu@unmus.ac.id
}

\begin{abstract}
This study aims to develop the skills of Indonesian language skills for junior high students (1), especially on the skill of writing narrative. explaining the misuse of Indonesian language in the narrative text of the seventh grade students of Junior High School Gudang Arang in Merauke the academic year 2018/2019 (2); cause of error (3), and efforts made by teachers and students to solve the Indonesian error (4). This research is a qualitative descriptive research by analyzing the narrative essay of class VII students of Junior High School Gudang Arang in Merauke. The techniques used in this study are interview and documentation techniques, in depth interviews and analysis of student narrative essays. Data analysis techniques used are interactive analysis model consisting of four components, namely data collection, data reduction, data presentation, and verification of data to be analysed.
\end{abstract}

Keywords: analysis, writing skill, narrative essay

\section{INTRODUCTION}

The function of the Indonesian language itself as a means of interacting, as a unifying tool of the nation, as a means of developing national culture, science and technology and as the official language of the State. In the phenomenon that occurs, many students consider that learning Indonesian is an easy lesson, but on the contrary because Indonesian requires a relatively long time to understand it specifically, for example in students' writing skills [1]. Writing skills are an aspect of delivering messages or content by using written language as a medium. Writing in the form of a symbol or symbol of language can be seen in accordance with the conventions of the language user community. Writing skills are related to the ability to express ideas in an essay, so writing skills are one type of language skills that must be mastered by students because writing skills in students need to be trained continuously. In the aspect of writing skills will sharpen the sensitivity of students in sensitivity to mistakes both spelling, structure and about the use of diction.

So the purpose of teaching Indonesian language in particular is writing so that students are able to express ideas and experiences and feelings in writing and in accordance with the theme and context. The purpose of language mistake analysis is traditionally very practical, namely as feedback for the sake of compiling language learning material. [2] That narration is a form of writing that tries to create. narrating, coupling the actions of human actions in an event chronologically or which takes place in a single unit of time. The purpose of writing narrative essays is to tell a series of events to the reader clearly, so that the reader feels that they are experiencing the events that are told. Expository narrative essays can help students absorb and process information, and think actively and can express feelings by writing essays, especially narrative essays. In order to be skilled in writing, it requires regular teaching and skills, and in writing narratives students will be required to combine two imagination and reasoning skills to train students' intellectual intelligence.

The success or failure of teaching Indonesian is determined by several factors including the factors of students and teachers in providing narrative essay writing lessons. So that students are required to be able to express their feelings and ideas in a systematic, coherent and complete manner [3]. States that the level of student understanding narrative essays from 10 students is devided into four levels of understanding narrative essays from 10 students is divided into four levels of understanding categories, 2 people $(22.2 \%)$, extraordinary categories, 4 people $(44.4 \%)$, good categories, 1 person $(11.1 \%)$ fair, poor, very poor, 3 people $(33.3 \%)$ fair categories show that of the four aspek students the ability to understand narrative texts is still in the low category in determining the main idea because students feel bored and less enthusiastic in learning.

But in reality students are still experiencing problems including the presence problems including the presence of boredom an poor mastery of language rules. Many teachers complain about mastery of students' language in writing essays. So that in the learning process the teacher must be able to use learning media, [4]. Explained that media is everything that can be used to be able to channel messages from senders to recipients of messages in order to stimulate students' thoughts, feelings, concerns, and interests in such a way that the learning process can occur. The use of these media to help stimulate students 'attention to the material being conveyed and also so as not to give rise to other perceptions in students' learning process, so that in the learning process students can express their ideas and ideas 
regularly, so in this study students must write using media learning that has been provided by using serial image media in writing narrative essays. The aspects studied in the language error analysis activities used by researchers in this study analyzed language errors in terms of three aspects, namely spelling errors, morphological errors and diction.

Spelling mistakes are mistakes in describing words or mistakes using punctuation. In the spelling the following matters are regulated: (1) Writing of Capital Letters (Uppercase), (2) Writing of Italic Letters, (3) Writing of Words, (4) Writing of Symbols of Numbers, (5) Writing of punctuation, such as periods, commas, semicolons, colons, question marks, exclamation points, hyphens, quotes, single quotes, parentheses, square brackets. [5] explains, morphology is a process of forming words from a basic form through affixing, repetition, merging, and abbreviation. Morphological processes involve components (a) the basic form, (b) forming tools, (c) grammatical, (d) the results of the formation process. Morphological errors are errors that are caused by choosing the wrong affix, wrong using the word repeat, wrong composing compound words and choosing the wrong word form. Many language errors in morphology are in written language.

Dictation is the choice of words that someone uses to express certain ideas with the right words. The accuracy of the choice of words is intended not to cause different interpretations between the writer or speaker and the reader or listener. The results of analysis of language errors in students writing errors must be avoided. Therefore language errors must be reduced. This can be minimized if the Indonesian language teacher can thoroughly examine all the ins and outs of language errors. [6] That errors caused by fatigue, fatigue, and lack of attention, are called performance factors, this performance error is an appearance error, in some literature it is called mistakes, and errors caused by lack of knowledge about language rules referred to as a competency factor. This error is a systematic deviation caused by the knowledge of students who are developing about the system The second language is called errors.

In the process of learning a second language one often experiences errors in language learning. So that mistakes made by learners need to be analyzed in language errors, the analysis aims to help learners in understanding the material and reduce language errors that occur. [7] That in the work procedures analysis of language proficiency performed by language teachers and language researchers in these activities includes collecting samples of language errors, identifying language errors and seriously evaluating language mistake. That there are several factors that cause language errors, among others, the first is the error factor, appearance, and in some factors the literature and the second factors is lack of knowledge about language rules which are systematic deviations regarding the system the second language is called a competency factor or mistake.

\section{RESEARCH METHODS}

This research is a qualitative descriptive study with a type of case study research. [8] qualitative research methods are more emphasized in the aspect of understanding in depth to see problems in a problem. The object in this study is the results of writing students 'narrative essays by looking for students' use of Indonesian language errors in linguistic reviews such as the use of spelling, morphology and diction.
Analysis of Indonesian language errors reviewed through a linguistic review of spelling mistakes, morphological use, and diction. The data collection technique used in this study is the observation technique which is done by getting research data by observing. Observations related to research are looking for information about the background language used by students and teachers in the learning process in Class VII Junior High School Gudang Arang. The second data collection technique is collecting data by giving tests to students using serial media and written directly by students by making narrative essays.

The data source in this study is the result of writing students 'narrative essays by looking for students' use of Indonesian language errors in linguistic reviews such as the use of spelling, morphology and their dictionaries. This research is a type of case study research because the data analyzed in this study are narrative essays that have been made by students, then the results of students' narrative essays will be analyzed aspects of Indonesian language errors through linguistic review, among others: the use of spelling, the use of morphology and diction to find out to what extent student's level of understanding in learning Indonesian [9]. This research was conducted for four months and the location of this study was carried out in one of the Schools in Merauke, namely the Preparatory Middle School of the Gudang Arang Merauke. Data obtained from documents in the form of the results of writing narrative essays of students in class VII of Gudang Arang School and based on the results of interviews from Indonesian Language Subject teachers.

This study discusses the use of Indonesian in the learning process in the classroom. Data collection techniques used in this study are observation techniques carried out by obtaining research data, namely by making observations. Observations relating to research are looking for information about the language background used by students and teachers in the learning process in Class VII of Gudang Arang School. The second data collection technique is to collect data by giving tests to students using serial images and written directly by students by making narrative essays. After giving tests to students, students are then interviewed by communicating in dialogue and question and answer with informants directly and openly. This interview technique is used to find out information about the learning system and the learning conditions of students in the classroom to determine the extent to which students' understanding of using Indonesian in written form, for example writing narrative essays.

Next, the researcher will collect the results of students' writing in the form of narrative essays and then analyze so that they can determine the level of errors in the narrative essays of students through documentation techniques. [10] In work procedures language error analysis commonly used by language researchers and teachers consists of collecting samples, identifying errors contained in the sample, explaining the language errors, classifying errors based on the cause and evaluating or evaluating the level of seriousness of errors that is. Language errors and language errors are different from language errors. Although the two terms are indeed forms of deviant speech usage. Language errors occur systematically because there is no mastery of the language system rules in question. Whereas language errors do not occur systematically. randomly, not because they have not mastered the language rules system in question, but 
because failure to realize a system of language rules that has actually been previously controlled or because of performance factors, for example because of limitations in remembering something that sounds wrong in words, said, word order, pressure words or sentences that are random at the linguistic level. Actually mistakes can be corrected if the students concerned are introspective, more aware or focused on correcting their own mistakes. Conversely language errors usually occur consistently and systematically.

Errors usually last long if not corrected. The improvement can be done by the teacher, for example through remedial, training, practice and so on. In the data analysis technique in this study consists of five stages, among others, namely first through the identification phase, namely by identifying activities with language errors in the narrative essay of students and given a code on data that has been found and entered into the table format analysis of three errors language error aspects, namely in terms of linguistics determined at the beginning of the study, namely spelling, morphology and diction, then the second data analysis technique is at the categorization stage of data that has been identified based on the narrative essay VII grade students of Gudang Arang class then categorized accordingly. specifically based on aspects of spelling mistakes, morphological errors and diction.

After the data is categorized, then the third stage of the next data analysis technique is the data calculation technique, namely by calculating the number of errors in the Indonesian language of students in essays of class VII students of the Gudang Arang Merauke School, then the data is presented by displaying data in the form of later percentages interpreted in descriptive form and then the last stage in this data analysis technique is the stage of drawing conclusions, namely by concluding data that has been identified and categorized according to the formulation of pre-existing problems by checking the validity data in accordance with the activity of checking experts and checking theory. Analysis of Indonesian language errors reviewed through a linguistic review of spelling mistakes, morphological use, and diction. The data collection technique used in this study is the observation technique which is done by getting research data by observing.

Observations related to research are looking for information about the background language used by students and teachers in the learning process in Class VII Junior High School In Gudang Arang Merauke. The second data collection technique is collecting data by giving tests to students using media of serial images and written directly by students by making narrative essay [11].

After giving the test to the students then the students were interviewed by communicating in dialogue and questioning with the informants directly and openly. This interview technique is used to find out information about the learning system and the conditions of student learning in class to find out the extent of student understanding in using Indonesian into written form for example writing narrative essays. Furthermore, researchers will collect the results of student writing in the form of narrative essays and then analyzed in order to find out the level of errors in students' narrative essays through documentation techniques [9].

While language errors do not occur systematically or randomly, not because they have not mastered the language rules system in question, but because of a failure to realize a language system that has actually been mastered before or due to performance factors, for example due to limitations in remembering something that causes errors in pronouncing language sounds, said, word order, word stress or random sentences at the linguistic level. Actually mistakes can be corrected if the student concerned is introspective, more aware or focused to correct his own mistakes. Instead language mistakes usually occur consistently and systematically. Mistakes usually last a long time if not corrected. Improvements can be made by the teacher for example through remedial, practice, practice and so on. Errors are a representation of students' understanding of the language system that they are learning is apparently lacking so that mistakes often occur. But language errors will decrease if the level of understanding increases.

Indonesian subjects are tested in the National Examination. Therefore, Indonesian subjects are important as a basis in developing aspects of Indonesian language skills in students. Development of language skills Especially aspects of writing need to get attention starting from the most basic education, because writing skills are not obtained suddenly. The author acts as a historian or storyteller, but he has a specific purpose. So in writing students can minimize the level of student language errors, the lower the achievement of language teaching so that efforts are needed to minimize language errors. Language errors are systematic deviations caused by students' developing knowledge of the second language system called errors.

Analysis of Indonesian language errors in students, especially at the junior high school level, is very important to do because learning in Indonesian begins with the aspect of writing skills requiring the ability to put ideas into written language in a systematic, complete and clear manner so that they can be well communicated to the reader. Analysis of Indonesian language errors in terms of students' linguistic aspects including spelling errors, morphological errors and diction. Through research into language error analysis in students' narrative essays can be minimized and Indonesian Language teachers can study more deeply through the students' language learning process, especially in students' language mistakes in narrative essays of VII grade students at Gudang Arang Merauke Middle School.

\section{RESUlt AND Discussion}

In this section, the data will be presented in the form of research results and discussions that include (1) data on spelling errors, (2) data on word formation errors (morphology) and (3) data on word choice errors in narrative essays students of class VII Gudang Arang Merauke. The results were found through the frequency of spelling mistakes made for example in respondent two, spelling misuse four times, morphology once, and diction twice. Errors lie in sentences one, five, and four. Misuse of spelling, morphology and jurisdiction in narrative essays "Playing warfare" Respondents three. Error using spelling in the 1st sentence. The 1st sentence is found to be misused four times. Excerpt contained in 1st sentence " Pada suatu hari : NANDO, OTIS, dan yan pulang sekolah. Mereka bersepakat untuk pergi bermain bersama-sama setelah makan siang. " The sentence does not use proper punctuation, both in the use of a colon (;), and the writing of a person's name. 
Thus, the sentence can be corrected into the following sentence. " Pada suatu hari, Nando, Otis, dan Yan pulang sekolah. Mereka bersepakat untuk pergi bermain bersamasama setelah makan siang." The 5th sentence found a diction error which is in the quote sentence "Mereka berjalan ke tempat tujuan dan telah sampai. Mereka atur permainan langsung." The sentence has an incorrect diction should be "Mereka berjalan ke tempat tujuan dan setelah sampai, mereka langsung mengatur permainan." The 6th sentence also has an inappropriate diction. "Mereka kemudian membagi kelompok menjadi dua. Adi dan Gusti, Budi dan Adi." The 7th sentence also has a diction error which is in the sentence quote. "Setelah membagi orang langsung membagi arah adi dan Gusti ke arah kiri Budi dan adi ke arah kanan supaya bersembunyi." The sentence should be corrected to " Setelah membagi kelompok mereka kemudian membagi arah. Adi dan Gusti ke arah kiri sedangkan Budi dan Adi ke arah kanan untuk mencari tempat bersembunyi." Error using morphology is then found in the 5th sentence. The sentence was found a one-time morphological error, namely, " OTIS terkena luka, teman perempuannya yang bernama Eta dan Elce, mereka berdua yang berobati OTIS sehingga Otis pun merasa tenang." The sentence was incorrect. Thus, the sentence can be corrected into the following sentence. "Otis terluka, teman perempuannya yang bernama Eta dan Elce, yang mengobati luka Otis, sehingga Otis pun merasa tenang." Error Using Dictation in fourth Sentence.

The fourth sentence was found to use the diction twice. Excerpt contained in the fourth sentence "Mereka teman yang bernama NANDO dan OTIS keasyikan bermain baku tembak." The sentence does not use the correct diction. Thus, the sentence can be corrected into the following sentence. "Teman mereka yang bernama Nando dan Otis keasyikan bermain tembak-tembakan." Error using morphology is then found in the fiveth sentence. The sentence was found a onetime morphological error, namely, " OTIS terkena luka, teman perempuannya yang bernama Eta dan Elce, mereka berdua yang berobati OTIS sehingga Otis pun merasa tenang." The sentence was incorrect. Thus, the sentence can be corrected into the following sentence. "Otis terluka, teman perempuannya yang bernama Eta dan Elce, yang mengobati luka Otis, sehingga Otis pun merasa tenang." Error Using Dictation in forth Sentence. The fourth sentence was found to use the diction twice.

Excerpt contained in the 4th sentence "Mereka teman yang bernama NANDO dan OTIS keasyikan bermain baku tembak." The sentence does not use the correct diction. Thus, the sentence can be corrected into the following sentence. "Teman mereka yang bernama Nando dan Otis keasyikan bermain tembak-tembakan." The four sentence found a spelling error once. The quote contained in the four sentence "Kedua suster itu, langsung bergegas mengambil obat dan langsung mengobati teman saya yg bernama Merlin." The sentence does not use the right punctuation that is in the word. Thus, the sentence can be corrected into the following sentence. "Kedua suster itu, langsung bergegas mengambil obat untuk mengobati teman saya yang bernama Merlin.”

(1) Mistakes The use of Morphology in the one st and two nd Sentences in the word main and kumpul words must be given a ber- prefix that changes to bermain and bekumpul. Then the word atur must be given a meN prefix which turns into a mengatur because of the morphophonemic process, which is the phoneme change process that occurs in word formation due to morpheme encounters with other morphemes resulting in nasal sounds and resulting allomorphs that are formed when they meet the basic words first letter. The five sentence in the word kena be given a terperfix that the word hit changes to the a terkena. The six sentence of the luka must also be given a ter- prefix so that the wound turns into an terluka.

(2) The one st to eight sentence is found to be fifteen times wrong in using diction. Excerpt contained in the first sentence "adi megajak teman-taMannya kawan-kawan sebentar kita berMain ya." The sentence does not use the correct diction because the sentence is in the form of an indirect sentence should add a word mengatakan and add a conjunction bahwa the sentence changes to "Adi mengatakan kepada teman-temannya bahwa mereka akan bermain." While the second sentence is a direct sentence that mimics someone's conversation as said. So that in the sentence should use the bertanya, the quotation is enclosed in quotation marks two, use the first pronoun of the plural person, namely us and in the sentence of quotation begins with a capital letter found in the phrase "kata Gusti tapi main apa" is a direct sentence that should Kemudian Gusti bertanya, " Kita akan bermain apa?" The sentence is also given the word conjunction kemudian, then to state the order of things.

The third sentence was found an error as in the quote sentence "main baku tembak kata Budi tapi kita pulang makan dulu ya." The sentence is a direct sentence and in the form of Budi's answer to Gusti's question that should have changed to " Bermain tembak-tembakan tetapi kita pulang dulu ke rumah untuk makan, jawab Budi." Based on the analysis of the data found in one of the example sentence quotes from the Respondent 1 sentence to 1 word yg short which should not be an abbreviation commonly used in proper Indonesian grammar. This finding proves that students are not careful in using spelling. This inaccuracy occurs because students are not interested in the learning material delivered by the teacher in class. The teacher should be able to provide a fun language learning method for students, especially in writing skills. lowercase letters at the beginning of sentences and lowercase letters for people's names.

Based on the results of data analysis found in one of the example excerpt sentences from Respondent 20 in the 4th sentence "lalu mereka berkumpul untuk bermain bersama." This sentence was found not to use capital letters at the beginning of the sentence. Yet in the spelling of each letter writing at the beginning of the word in the sentence must be written in capital letters. Then in the analysis of the data found, writing the name of the person written in lower case at the beginning of the word, for example in one of the example citation sentences from Respondent 23 in the sentence "leo, agus, bayu dan titus adalah teman kelas." The sentence does not use capital letters at the beginning of the word for writing people's names. Though it should be in the spelling of people's names must be written using capital letters.

The four sentence is found to be a mistake as in the quotation of the words "kata andi oke sebentar kumpul di tempat selalu Ya Bro". The word in the place is always not right because it will make the meaning unclear and the word Bro is a prokem or slang language of young people now that 
makes Indonesian experience a language shift. The second sentence found a spelling error of three times, namely the writing of the person's name should be capital letters, namely in the word Andi and the word ya whose writing must be lowercase and at the end of the sentence is given an exclamation mark. So that the sentence should turn into a direct sentence given the addition of words and flanked by two quotations and given a conjunction then to state the order of things and the fourth sentence should change to "Lalu Andi berkata,"oke sebentar kita akan berkumpul di taman teman-teman."

The 8th sentence found a diction error that is in the quote phrase "dan setelah membagi orang dan mereka bermain" lies in the use of the word dan also the use of the word setelah in all previous sentences is a conjunction that is too often used so that the word dan also the word setelah it is replaced with the word then and eliminates words and also words divide people. The 9th sentence found a diction error which is in the quote sentence "setelah bermain Budi menembaki Gusti dan tangannya kena" the same as in the 8th sentence the word and also the word after being removed and replaced by the conjunction namun as a conjunction of cause and effect and the addition of the word saat, in the sentence also it was found that the diction of his hand had been hit improperly and he should have been shot so that the 9th sentence his improvement should have been "Namun saat mereka bermain Budi menembak Gusti dan tangannya terkena tembakan. In the 10th sentence also found an error using diction in the sentence "Mereka membawa Gusti ke Siti dan Sinta untuk diobati karena luka. The word karena luka the wound was not right and replaced with a sentence so that the wound agar lukanya diobati so the 10th sentence should be "Mereka membawa Gusti ke Siti dan Sinta agar lukanya diobati."

Based on the sample analysis results above, the frequency level of language errors contained in the narrative essays of class VII students at Arang Merauke Middle School were reviewed in terms of linguistics, namely spelling, morphological and diction usage errors, which were presented in the calculation data for percentage error in the class VII students. The Arang Merauke Preparation Middle School is as follows:

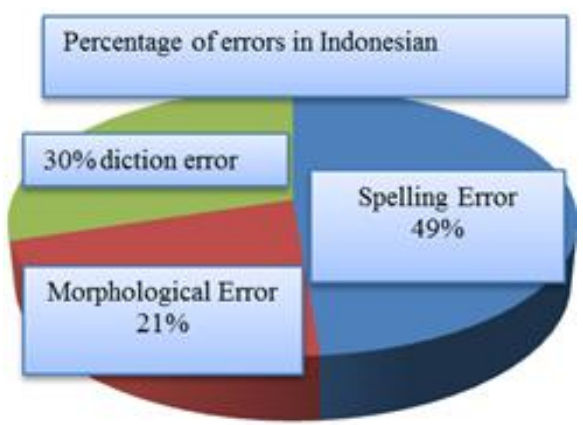

Fig. 1. Precentage of erros in Indonesia language of students class VII Junior High School Gudang Arang in Merauke, (a) diction error 30\%, (b) spelling error $49 \%$, (c) Morphological error $21 \%$

Based on data analysis found in the First error in terms of spelling as many as 75 errors reached $49 \%$. Misuse of spelling done by students in this narrative essay occurs in several aspects, namely aspects of writing punctuation, writing letters and writing words. Errors in the use of spelling found in narrative essays of Grade VII students of
Merauke Warehouse Middle School include: (1) the use of punctuation in sentences is not appropriate. The use of punctuation is a comma in a sentence that is not right and replaces the dot. (2) Errors in the use of punctuation found in data analysis, namely a dot that is not used at the end of a sentence, does not use an exclamation point at the end of a command sentence and a comma at the end of a sentence is found in data analysis read, that is the point, exclamation point and comma properly. In spelling punctuation is something that must be considered in the sentence, because punctuation is used to separate one sentence from another in the essay. (3) the writing of prepositions that combine with the accompanying words In writing the preposition must be combined with the name of the accompanying place. (4) writing of particles which are arranged in the words that precede them. (5) writing of abbreviations that are not in accordance with the provisions. (6) writing the spelling of letters in an incorrect word.Spelling mistakes made by students prove that students don't practice writing according to the correct grammar.

These errors are caused by the habits of students everyday when speaking or speaking so students will use punctuation in their writings based on the pauses in the sentence they say then they write in the essay. Based on these findings in accordance with the opinion of [12] it is explained that in the Enhanced Spelling Guidelines book, there are instructions for using the right spelling starting from the letters writing rules, word writing and the use of punctuation but are still often incorrect. There is a misspelling that can make the quality of writing not good. Misuse of spelling also occurs because when students get writing assignments, the teacher does not provide discussion of student writing errors based on grammar in accordance with the terms of writing in spelling.Then based on the results of the second percentage of language errors reviewed in terms of the morphological level of the percentage level of $21 \%$. Based on the data analysis found 33 morphological errors. Errors in the use of morphology carried out by students in this narrative essay occur in the aspect of using prefixes that do not match the words they are attached to and do not use prefixes on the base words. Errors in the use of morphology found in narrative essays of Grade VII students of Gudang Arang Middle School in Merauke include: (1) the use of morphology that occurs in affixation processes, namely the use of prefixes based on data analysis found, (2) the use of the meN-prefix which is not used in the set word as in the analysis of the data found.

Based on the findings of morphological errors made by students prove that students do not understand the use of affixation attached to the basic words. The affixation [13] Morphology is part the process is a part of linguistics. In the opinion of morphology is part of the science of science of language that learns the ins and outs of the form of words to the function of changing words and meaning of words. In the field of morphology there is an affixation process that is a linguistic form whose existence is to meanings to the form it attaches. The affixation process or the filling process can be divided into four types including (a) prefixes that are affixes attached to the front of the basic word form or prefixes for example me-, di-, ter-, per, se-, pe-, ke-, etc., (b ) infix is the affix attached in the middle of the basic word forms such as -el-, -em-, and -er-, (c) the suffix is the affix attached behind the basic word form or called the final affix, for example -i, -kan, -wan, etc. (d) Confix is a combination 
of prefixes and suffixes that are inherent in the basic words such as the things, ideas, things, etc.

The affirmation process experienced in the basic words will affect the meaning of the word after getting the prefix at the beginning of the basic word But students understanding of the provisions of the use of morphology in student essay data is not appropriate. Because of the lack of attention of the teacher to teach the use of morphology in the basic words as a result students do not understand the use of morphology in the formation of words that should be. Furthermore, based on the results of the second percentage of language errors reviewed in terms of the level of morphology of the percentage level of $21 \%$. The use of nonstandard word choices is because students who hang out everyday often use non-standard words in communication, eventually this habit is used also in written language.

So that errors in the use of this standard word are found in students' narrative essays. Students should pay attention to the use of words that have been standardized. Therefore, the language teacher must also improve the quality of the students' vocabulary in choosing the right words in the sentence Incorrect mistakes in word choices are also found in students' narrative essays. This error is caused by the choice of words that are not coherent with the sentence. This happens because the accuracy of the use of word choices is influenced by the ability to use language such as the ability to understand, master, know the use of vocabulary appropriately, so as to be able to express ideas correctly to communicate it to the reader. Word choice errors also occur because students have limited use of vocabulary due to students who lack reading in spelling and reviewing vocabulary properly and correctly. So students can have mastery and vocabulary vocabulary and improve and increase the vocabulary student have.

\section{CONCLUSION}

Based on the results of data analysis and discussion obtained in the narrative essay there are several conclusions, among others, the first misuse of spelling in the narrative essay of class VII students of Gudang Arang School in Merauke was found in several aspects, namely aspects of punctuation, word writing and letter writing. Misuse of spelling occurs because students do not understand the provisions of proper spelling in narrative essays written by students. Then the second language error found in the narrative essay of students is the misuse of morphology in the affixation. process that is less noticed and does not master the formation of words with good affix. This is very important to note because each formation of a word of affix must be in accordance with the meaning contained in the word. Therefore, the more vocabulary mastered by students, the more vocabulary students have. The third language error found in the narrative essay of students is that the use of diction in the narrative essay of students is found in two aspects, namely the lexis aspect and the grammatical aspects. Error using diction is caused by the lack of vocabulary students have so students cannot convey their ideas appropriately.

Based on these conclusions, it is suggested (1) that Indonesian language teachers pay more attention to the use of punctuation correctly, paying attention to the writing of capital letters and the right choice of words in the narrative essay of students. Thus students can multiply the quality of vocabulary use to facilitate the use of student language in written languages to convey ideas and ideas, (2) Teachers must provide students with an understanding of the use of spelling, morphology and diction in the students essays. (3) giving training to students in writing and reading, listening and discussing with Indonesian teachers. (4) it is expected that this research will be carried out in subsequent research similar to the research subject in junior high school students so that students are accustomed and trained to writing by paying attention to spelling, the use of morphology and diction properly.

\section{ACKNOWLEDGMENT}

This article was written based on the research conducted by the support of Rector of University and the Dean of teacher training and education faculty of Musamus Merauke University, so the writers convey the big thank for the material and spiritual support. We would like to say thanks to the Rector of Musamus university Merauke who has facilitated the research and writing of this article, also to our fellow research team and writers. Thanks also to the Committee of International Conference on Social Science (ICSS) and the Atlantis Press Publisher which has facilitated the publication of this article.

\section{REFERENCES}

[1] Suparno dkk, Meningkatkan keterampilan Berbahasa Indonesia. Bandung: CV. Karya Putra, 2012.

[2] Nurudin, Dasar-Dasar Penulisan. Malang.: ITMM Press, Malang., 2007.

[3] A. S. et Al., ", "The Ability to Understand Narrative Text of the Second Semester Students of Indonesian Language And Literature Academic Year 2017 / 2018 of Musamus University,", ICSS, vol. 226, p. vol. 226, Icss, p. 1388-1393, 2018.

[4] A. S. et Al., "The Ability to Understand Narrative Text of the Second Semester Students of Indonesian Language And Literature Academic Year 2017 / 2018 of Musamus University.," ICSS, vol. 226, p., vol. 226, 2018.

[5] A. Chaer, Morfologi Bahasa Indonesia: Pendekatan Proses. Jakarta: Rineka Cipta, 2008.

[6] S. Pringgawidagda, Strategi Penguasaan Berbahasa. Yogyakarta: Adi Cita Karya Nusa., 2002.

[7] N. Setyawati, Analisis Kesalahan Berbahasa Indonesia. Surakarta: Yuna Pustaka., 2010.

[8] Sugiyono, Metode Penelitian Kuantitatif, Kualitatif, Dan R\&D. Bandung: Penerbit Alfabet, 2012.

[9] N. H. Nurdiansah, Tobias Ngaruaka, "Relationship OF The Power Of The Diksi With The Writing Of Drama," ICSS, vol. 383, 2019, doi: https://doi.org/10.2991/icss-19.2019.203.

[10] H. G. Tarigan, Menulis sebagai Suatu Keterampilan Berbahasa. Bandung: Penerbit angkasa., 2008.

[11] R. Uspayanti, N. Manuhutu, R. Butarbutar, M. Bawawa, Marnina, and N. Habeahan, "Enhancing Literal and Interpretive Reading Comprehension through Collaborative Strategic Reading," vol. 383, no. Icss, pp. 98-104, 2019, doi: 10.2991/icss19.2019.204.

[12] K. Ariningsih, N. E., Sumawarti, \& Sadhono, “Analisis Kesalahan Berbahasa Indonesia dalam Karangan Eksposisi Siswa Sekolah Menengah Atas," J. Penelit. Bahasa, Sastra Indones. dan Pengajarannya, 2012.

[13] M. Ramlan, Deskripsi., Morfologi suatu tinjauan. Yogyakarta: CV. Kanjono, 2001. 